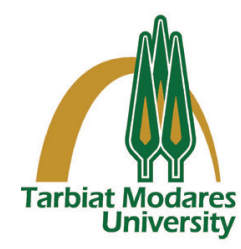

\title{
A Cross-Immunity between SARS-CoV-2 and MERS-CoV: Interest in Anti-SARS-CoV-2 Serotherapy Development Using Dromedary Serum
}

\section{A R T I C L E I N F 0}

\section{Article Type}

Review Article

\section{Authors}

Abdeslam Jaafari, $P h D^{1^{*}}$

Souad Lekchiri, $P h D^{1}$

Hafida Zahir, $P h D^{1}$

Mostafa Ellouali, $P h D^{1}$

Abdallah Badou, $P h D^{2}$

Hassan Latrache, $P h D^{1}$

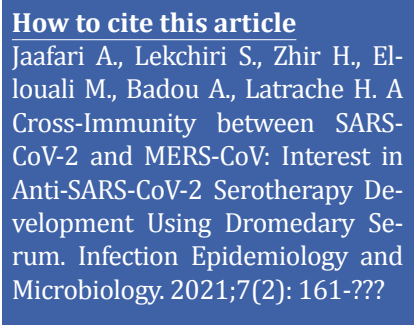

${ }^{1}$ Bioprocess and Biointerface Laboratory, Faculty of Science and Techniques, Sultan MoulaySlimane University, BP: 523, BeniMellal, 23000, Morocco ${ }^{2}$ Cellular and Molecular Pathology Laboratory, Faculty of Medicine and Pharmacy, University Hassan II, Casablanca, Morocco

\begin{abstract}
A B S T R A C T
Backgrounds: A potential cross-immunity between SARS-CoV-2 and MERS-CoV could lead to the development of a serodiagnostic test and/or serotherapy against SARS-CoV-2 using dromedary camel anti MERS-CoV serum.

Materials \& Methods: Epidemiological and 66 literature data, of which 35 have been published during 2015-2021, and findings were analysed.

Findings: According to the statistical data reported during COVID-19 pandemic, there are less cases and deaths associated with COVID-19 in countries known for dromedary breeding and the circulation of MERS-CoV (another betacoronavirus disease transmitted by dromedary camels) among humans and dromedaries. This observation and the similarity in genome and immunopathogenicity between SARS-CoV-2 and MERS-CoV, suggest that individuals who have been in contact with MERS-CoV infected dromedaries and/or consumed their products (milk, meat, urine) might have acquired an immunity protecting them against SARS-CoV-2. In addition to neutralizing antibodies, this immunity could also be due to complement proteins, chemokines, and especially antimicrobial peptides (AMP), known for their effect on enveloped viruses.

Conclusion: Most research has focused on vaccines as a solution to stop the pandemic, while serotherapy hasn't significantly aroused the interest of researchers. This potential cross-immunity between SARS-CoV-2 and MERS-CoV could lead to the development of a serodiagnostic test and/or serotherapy against SARS-CoV-2 using dromedary camel anti MERS-CoV serum.
\end{abstract}

\section{Keywords: SARS-CoV-2, MERS-CoV, Cross-immunity, Serotherapy.}

\section{CITATION LINKS}

[1] Durand J, Jacquet M, Paillard L, Rais O, Gern L, ... [2] Bhattacharyyaa S, Gestelandc PH, Korgenskic... [3] Salazer G, Zhang N, Fu TM, ... [4] Beigel JH, Tebas P, Elie-Turenne MC, Bajwa... [5] Gupta P, Kamath AV,ParkS, Chiu H, Lutman J, ... [6] Beltramello M, Williams KL, Simmons... [7] Robbie GJ, Crist R, Dall'acqua WF, Jensen K... [8] Carbonell-Estrany X, Simões EA, Dagan R, Hall CB, ... [9] Caskey M, Klein F, Lorenzi JC ... [10] Welburn SC, Coleman PG, ... [11] Haagmans BL, Al Dhahiry SH, ... [12] Paden CR, Yusof M, Al Hammadi ZM, Queen... [13] Aguanno R, ElIdrissi A, Elkholy AA, Ben ... [14] Mehand MS, Al-Shorbaji F, Millett P... [15] Zaki AM, van Boheemen S, Bestebroer ... [16] World Health Organization (WHO). Middle ... [17] Miguel E, Chevalier V, Ayelet G, Ben... [18] Sikkema RS, Farag EABA, Islam ... [19] worldometer: https://www.worldometers. info/coronavirus... [20] Ministère de la santé, Portail Officiel du Coronavirus au Maroc, http://covidmaroc. ma/Pages/Accueil/AR.aspx... [21] Minitère de la ... [22] Fehr AR. and Perlman S ... [23] Su S, Wong G, Shi W, Liu J... [24] Chen Y, Liu Q Guo D... [25] de Wit E, van Doremalen... [26] Wu F, Zhao S, Yu B, Chen YM ... [27] Huang C, Wang Y, Li X, Ren ... [28] Chan JF, Yuan S, Kok KH, To KK... [29] Nicholls JM, Poon LL, Lee... [30] Wong CK, Lam CW, Wu AK, Ip... [31] Prompetchara E, Ketloy, Palaga T. Immune... [32] Hussain S, Chen Y, Yang Y, Xu J, Pan J, Wu Y, et al... [33] Risco C, Anton IM, Enjuanes L, Carrascosa ... [34] Eckerle LD, Becker MM, Halpin RA, Li K, Venter... [35] Smith EC, Blanc H, Vignuzzi M, Denison MR. Coronaviruses... [36] Mahallawi WH, Khabour OF, Zhang Q Makhdoum... [37] Zumla A, Hui DS, Perlman S. Middle... [38] Perlman S, Dandekar AA. Immunopathogenesis of... [39] Liu W], Zhao M, Liu K, Xu K, Wong G, Tan ... [40] Liu W, Fontanet A, Zhang PH, Zhan L, Xin ZT... [41] Al-Abdely HM, Midgley CM, Alkhamis... [42] Li CK, Wu H, Yan H, Ma S, Wang L, Zhang M, etal. T cell... [43] Lu G, Wang Q Gao G.F. Bat-to-human: Spike... [44] Du L, He Y,Zhou Y, Liu S, Zheng BJ, Jiang... [45] Keng CT, Zhang A, ShenS, Lip KM... [46] Zhou T, Wang H, Luo D, Rowe... [47] Yang ZY, Kong WP, Huang Y... [48] Tai W, Wang Y, Fett CA, Zhao... [49] Chi H, Zheng X, Wang X, Wang C, Wang... [50] Cameron MJ, Ran L, Xu L, Danesh... [51] Leung DT, Tam FC, Ma CH, Chan... [52] Lin Y, Shen X, Yang RF... [53] Woo PC, Lau SK, Wong BH, Tsoi... [54] He Y, Zhou Y, Siddiqui P, Niu J, Jiang S. Identification... [55] Liu J, Wu P, Gao F, Qi J, Kawana... [56] Agnihothram S, Gopal R, Yount Jr BL... [57] Meyer B, Drosten C, Muller MA. Serological... [58] Du L, Ma C, Jiang S. Antibodies induced by... [59] Müller MA, Meyer B, Corman VM... [60] Abbad A, Perera RAPM, Anga... [61] Chouchane L, Grivel JC, Farag EA... [62] Traggiai E, Becker S, Subbarao... [63] Nie Y,Wang G,Shi X, Zhang H, Qiu Y,He Z, etal. Neutralizing... [64] Corti D, Zhao J, Pedotti M, Simonelli... [65] Wang L, Shi W, Joyce MG, Modjarrad K... [66] Hsieh IN, Hartshorn KL. The role of... 


\section{Introduction}

Cross-immunity is described as an acquired immunity against an infectious agent (virus or bacteria), which could also protect against another agent. Cross-immunity is related to the cross-reaction phenomenon. In general, each antibody is specific for one antigen but sometimes, some antibodies could link to other antigens with the same epitopes or similar structure, which suggests that cross-immunity could exist between microorganisms, especially those belonging to close families. This phenomenon is observed among some Salmonella species, for example, between Eberth bacillus and $S$. paratyphi A. In viruses, there is a crossimmunity between different strains of influenza virus due to Hemagglutinins $(\mathrm{H})$ and Neuraminidases (N). Those individuals exposed to a viral strain with a determined $\mathrm{H}$ (or $\mathrm{N}$ ) could be protected against another strain with a similar $\mathrm{H}$ (or N) ${ }^{[1-2]}$.

During the COVID-19 pandemic, researchers and healthcare professionals have talk a lot about vaccine but a little about serotherapy. Based on the cross-reactivity phenomenon, serotherapy could be a proper solution for many infectious diseases, especially viral infections. Serotherapy consists of the treatment via the administration of neutralizing antibodies recovered from the sera of infected and then cured individuals ${ }^{[3-4]}$. Influenza viruses ${ }^{[5-6]}, \mathrm{RSV}{ }^{[7-8]}$, and HIV ${ }^{[9-10]}$ are among the viruses mostly screened for antiviral serotherapy.

Objectives: This article sought to demonstratethrough observations, literature data, and data analysis that a potential cross-immunity between SARS-CoV-2 and MERS-CoV could lead to the development of serotherapy against COVID-19 using dromedary serum. This cross-reaction could also be used to develop a serodiagnostic test of SARS-CoV-2, using dromedary serum to detect SARS-CoV-2 antigens.
Observation: Less COVID-19 cases and deaths are reported in countries with dromedary breeding

Middle East respiratory syndrome coronavirus (MERS-CoV) disease is a viral infection transmitted to humans through infected dromedaries [11-12]. The first MERSCoV cases appeared in 2012 in Saudi Arabia [13-14]. According to WHO, 2468 MERS-CoV confirmed cases and 850 deaths were reported in 27 countries during 2012$2019^{[15-16]}$. It has been reported that this betacoronavirus is a zoonotic virus among dromedaries in the Middle East (especially in Arabian Peninsula), Pakistan, Bangladesh, as well as many African countries like Morocco, Ethiopia, Sudan, etc. [17-18].

According to the COVID-19 pandemic statistics until March 03, 2021, it could be observed that there is a remarkable difference in the total numbers of infected cases and deaths between countries with MERS-CoV circulation, due to dromedary breeding, and other countries with no dromedary breeding and therefore no MERS-CoV circulation. Table 1 represents some data showing this difference between three categories of countries. The countries in each category were chosen according to the presence or absence of dromedary breeding practice and MERS-CoV as well as the prevalence of MERS-CoV in humans. The list of countries in each category could be extended, but this will not have a significant impact on the results. Three categories are as follows:

- Category 1: Countries with no dromedary breeding and no MERS-CoV circulation (Germany, UK, France, Spain, and Italy)- Category 2: Countries with dromedary breeding and high prevalence of MERS-CoV in humans and dromedaries (Saoudi Arabia, UAE, Qatar, Oman, and Jordan)

- Category 3: Countries with dromedary breeding and moderate to low prevalence 
of MERS-CoV in humans (constituted essentially of African countries, including Morocco, Kenya, Ethiopia, Nigeria, and Burkina Faso)

In countries in Category 1, it could be observed that the total numbers of infected cases and deaths due to COVID-19 were high, while these two parameters were low in Categories 2 and 3. In Category 1 countries, the total number of infected cases ranged from $2.49 \mathrm{M}$ (million) in Germany to $4.19 \mathrm{M}$ in the UK, while the total number of confirmed cases ranged from 143000 (in Oman) to 408000 (in Jordan) in Category 2 as well as from 12071 (in Burkina Faso) to 485000 (in Morocco) in Category 3. Concerning total number of deaths, these values were around 70247 to 124000 (Spain/UK), 260 to 6510 (Qatar/Saudi Arabia), and 153 to 8653 (Burkina Faso/Morocco) in Category 1,2 , and 3 countries, respectively. Since the total number of reported cases may be influenced by the screening capacity of each country, the $\mathrm{D} / \mathrm{C}$ ratio (total deaths/ total cases) was calculated in percent (\%) to confirm observations. $\mathrm{D} / \mathrm{C}$ values ranged from 2.23 to 3.31 (Spain/Italy), 0.15 to 1.72 (Qatar/Saudi Arabia), and 1.23 to 1.78 (Nigeria/Morocco) in Category 1, 2, and 3 countries, respectively. The obtained D/C values showed that COVID-19 caused more mortality in Category 1 countries compared to the other categories. Furthermore, the difference observed between the Categories 1 and 3 would have been much higher if

Table 1) Distribution of the total number of infected cases and deaths due to COVID-19 in the three categories of countries until March 03, $2021^{\text {[19-20]. }}$

\begin{tabular}{lccccc}
\hline Countries & Total Cases & $\begin{array}{c}\text { Total } \\
\text { Deaths }\end{array}$ & $\begin{array}{c}\text { Total Cases/1M } \\
\text { Pop }\end{array}$ & Recovered & $\begin{array}{c}\text { Total Deaths/Cases } \\
\text { (in \%) }\end{array}$ \\
\hline Germany & $2.49 \mathrm{M}$ & 71852 & 87553 & $2.32 \mathrm{M}$ & 2.88 \\
\hline UK & $4.19 \mathrm{M}$ & 124000 & 62865 & $3.14 \mathrm{M}$ & 2.95 \\
\hline Spain & $3.14 \mathrm{M}$ & 70247 & 66808 & $2.74 \mathrm{M}$ & 2.23 \\
\hline France & $3.81 \mathrm{M}$ & 87542 & 56865 & 263500 & 2.29 \\
\hline Italy & $2.98 \mathrm{M}$ & 98635 & 49370 & $2.44 \mathrm{M}$ & 3.31 \\
\hline Saudi Arabia & $378 \mathrm{~K}$ & 6510 & 11030 & $369 \mathrm{~K}$ & 1.72 \\
\hline Qatar & $165 \mathrm{~K}$ & 260 & 71120 & $155 \mathrm{~K}$ & 0.15 \\
\hline Jordan & $408 \mathrm{~K}$ & 4793 & 40396 & $356 \mathrm{~K}$ & 1.17 \\
\hline Oman & $143 \mathrm{~K}$ & 1583 & 28600 & $133 \mathrm{~K}$ & 1.1 \\
\hline UAE & $399 \mathrm{~K}$ & 1269 & 40937 & $386 \mathrm{~K}$ & 0.31 \\
\hline Morocco & $485 \mathrm{~K}$ & 8653 & 13298 & $470 \mathrm{~K}$ & 1.78 \\
\hline Kenya & $107 \mathrm{~K}$ & 1866 & 2035 & 86914 & 1.74 \\
\hline Ethiopia & $162 \mathrm{~K}$ & 2391 & 1441 & $136 \mathrm{~K}$ & 1.47 \\
\hline Nigeria & $157 \mathrm{~K}$ & 1939 & 781 & $137 \mathrm{~K}$ & 1.23 \\
\hline Burkina Faso & 12071 & 153 & 595 & 11657 & 1.26 \\
\hline
\end{tabular}


Table 2) Distribution of COVID-19 cases in different regions of Morocco until March 03, 2021 [21].

\begin{tabular}{|c|c|c|}
\hline Regions & Total Cases & Total Cases/1M Pop \\
\hline Casablanca-Settat & 129300 & 18805 \\
\hline Rabat-Sale Kenitra & 51970 & 10801 \\
\hline Tanger-tetouan & 118855 & 33142 \\
\hline Marrakech-Safi & 80265 & 15952 \\
\hline Fes-Meknes & 78400 & 18280 \\
\hline Beni Mellal-Khenifra & 3381 & 1250 \\
\hline Oriental & 7590 & 2889 \\
\hline Deraa-Tafilalt & 9590 & 8230 \\
\hline Souss-Massa & 2652 & 703 \\
\hline Guelmim-Oued Noun & 1067 & 2464 \\
\hline Dakhla-Ouad Dahab & 970 & 6736 \\
\hline Laayoune-Sakya El Hamra & 1311 & 4189 \\
\hline
\end{tabular}

Total

all countries had the same level of health services. In fact, D/C values would have been considerably higher in Category 1 and much lower in Category 3.

In order to provide more evidencesupporting our hypothesis, the statistics of Morocco were analysed as it's a country where two regional categories were found: Saharian regions with dromedary breeding (Dakhla, Laayoune, and Guelmim) and regions without dromedary breeding (the other 9 regions of Morocco). The results summarized in Table 2 show a clear difference in the total number of COVID-19 confirmed cases between the two regional categories. In fact, total cases were 970, 1067, and 1552 cases in DakhlaOuad Dahab, Guelmim-Oued Noun, and Laayoune-Sakya El Hamra, respectively. By comparing Saharian regions to the other regions of Morocco, it was found that only $0.69 \%$ of cases were related to Saharian
485353

regions, while $99.31 \%$ were related to the other regions (Figure 1). Also, there was only 4463 cases/ 1M Pop in Saharian regions, whereas this parameter increased to 11313 in the other regions (Figure 2).

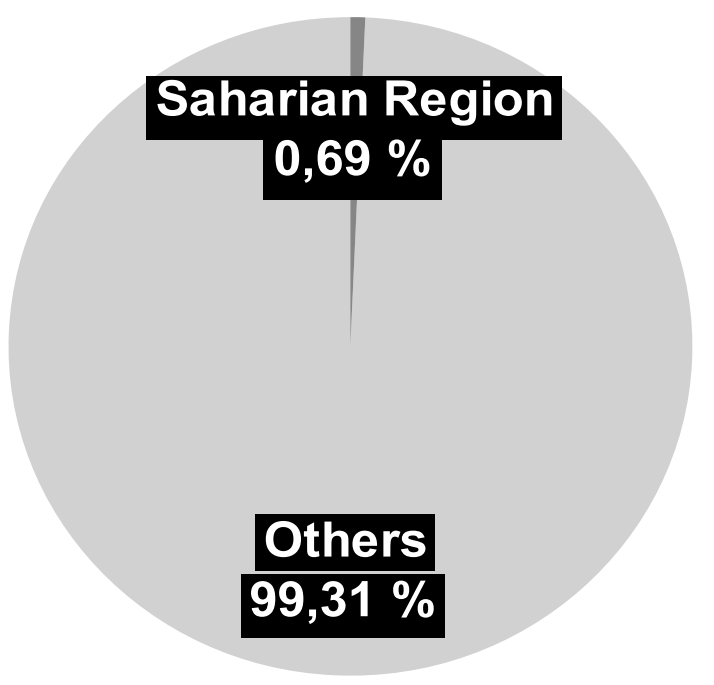

Figure 1) Distribution of COVID-19 total cases in Saharian regions and other regions of Morocco 


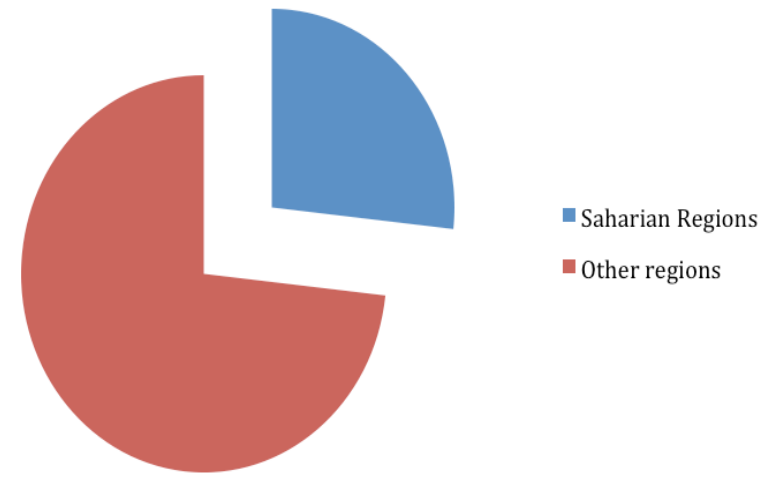

Figure 2) Total cases / 1M Pop in Saharian regions and other regions of Morocco

\section{Similarity between SARS-CoV-2 and MERS- CoVpathogenicity}

SARS-CoV-2 and MERS-CoV have the same pathogenic effect since they both cause severe respiratory syndrome in human by infecting lower respiratory tract [22-23]. Compared to MERS-CoV and SARS-CoV, it seems that SARS-CoV-2 infection is characterised by milder symptoms ${ }^{[24]}$. Other betacoronaviruses cause infections with different symptoms. In fact, Bovine CoV/ENT with cow as its host causes diarrhea, and Equine $\mathrm{CoV} /$ Obihiro12-1 with horse as its host, causes fever, anorexia, and leukopenia [25]. In addition to respiratory symptoms (cough, sore throat, and shortness of breath), fever and fatigue are the most common symptoms associated with SARS-CoV-2 and MERS-CoV infections. Diarrhea is rarely reported ${ }^{[26-28]}$. On the other hand, it has been reported that lymphopenia and "cytokine storm" of pro-inflammatory cytokines (IL-2, IL-7, IL-10, G-CSF, IP-10, MCP-1, MIP-1A, and $\mathrm{TNF} \alpha$ ) may play an important role in SARSCoV-2 and MERS-CoV immunopathogenicity [29-30]. This "cytokine storm" could lead to complications such as pneumonitis, acute respiratory distress syndrome (ARDS), respiratory failure, and potentially death ${ }^{[31]}$.

SARS-CoV-2 genome is similar to that of MERS-CoV

The genome of coronaviruses is a +ssRNA (single-stranded positive-sense RNA). Its size is about $30 \mathrm{~kb}$, the largest genome among RNA viruses, with a $5^{\prime}$-cap structure and a $3^{\prime}$-poly-A tail. The $3^{\prime}$ - terminus part of this genome encodes four main structural proteins, including spike (S), membrane (M), envelope (E), and nucleocapsid (N) proteins. Other parts of the genome encode many non-structural proteins (nsp). Most of these nsps are responsible for the virus replication [32-33]. Comparing different coronavirus genomes, it has been reported that there is $54 \%$ identity in the whole genome $58 \%$ in the nsp-coding region and $43 \%$ in the structural protein-coding region) between SARS-CoV-2 and MERS-CoV genomes ${ }^{[24,34-35]}$. SARS-CoV-2 and MERS-CoV immunity: Importance of $S$-protein as an inducer of immune response

In viral infections, innate immune response is mostly based on the type 1 interferon (IFN1) cascade that controls viral replication and subsequently induces adaptive immune responses. Clinical and experimental data as well as similarity between SARS-CoV-2 and MERS-CoV genomes led us to hypothesize that the host immune system may evade and response similarly to the infections caused by these two viruses. It has been reported that progression and severity of both SARS-CoV-2 and MERS-CoV infections, are characterized by an early high serum levels of pro-inflammatory cytokines (IP10, MCP-1, MIP-1A, and TNF .2 ) [27]. This finding suggests that there might be a similar cytokine storm-mediated disease severity induced by these two viruses [30, ${ }^{35]}$. Also, increased monocyte/macrophages have been observed in severe cases of both COVID-19 and MERS-CoV infections [36-37]. Humoral immunity is mediated by the secretion of substances in the blood or body fluids, such as antibodies, complement proteins, and certain antimicrobial peptides. In SARS-CoV-2 and MERS-CoV, immune 
Table 3) Comparison of genome and protein structure between SARS-CoV-2 and MERS-CoV (AA: Amino Acid, nsp: non structural protein)

\begin{tabular}{|c|c|c|}
\hline & SARS-CoV-2 & MERS-CoV \\
\hline Lengths & $29 \mathrm{~Kb}$ & $30 \mathrm{~Kb}$ \\
\hline Open reading frames & 11 & 11 \\
\hline Structural proteins & 4 & 4 \\
\hline Non structural proteins & $>5$ & 16 \\
\hline Spike protein & 1274 AA (S1: 936) & 1353 AA (S1: 1010) \\
\hline M protein & $223 \mathrm{AA}$ & $220 \mathrm{AA}$ \\
\hline E protein & $76 \mathrm{AA}$ & $83 \mathrm{AA}$ \\
\hline $\mathrm{N}$ protein & $420 \mathrm{AA}$ & $414 \mathrm{AA}$ \\
\hline \multirow{6}{*}{ Some non-structural pro } & nsp 1: 181 AA & $181 \mathrm{AA}$ \\
\hline & nsp 3: $1362 \mathrm{AA}$ & $1361 \mathrm{AA}$ \\
\hline & nps 5: $306 \mathrm{AA}$ & $305 \mathrm{AA}$ \\
\hline & nsp 7: 84 AA & $84 \mathrm{AA}$ \\
\hline & nps 11: 14 AA & $14 \mathrm{AA}$ \\
\hline & nsp 12: 932 AA & 933 AA \\
\hline
\end{tabular}

cells ( $\mathrm{T}$ and B) epitopes are built for the main four structural proteins $\mathrm{S}, \mathrm{N}, \mathrm{M}$ and $\mathrm{E}$ of the virus. Neutralizing antibodies limit viral infection by their protective effect and prevent the possible reinfection in the future ${ }^{[38]}$. Seroconversion occurs 4 days and 2-3 weeks after the onset of COVID-19 and MERS-CoV infections, respectively. In SARS$\mathrm{CoV}$ infection, neutralizing antibodies are found up to two years after infection ${ }^{[39]}$. For MERS-CoV, antibodies persist for at least one year ${ }^{[40]}$. In coronavirus infections, severe outcomes could be related to delayed and weak antibody responses [38].

It has been reported that most antigenic peptides are found in the structural proteins, especially spike protein ${ }^{[41]}$, which means that spike protein $(S)$ is not only responsible for receptor binding and membrane fusion of the virus to host cells ${ }^{[42]}$, but also plays a major role in both humoral and cellular immunity ${ }^{[43]}$. Since it's considered as the principal antigenic molecule, spike protein is used as a significant target for the development of vaccine. In fact, infection of Vero E6 cells by some SARS-CoV strains was shown in a study to be neutralized by anti-S1 antibodies (amino acids 485-625) ${ }^{[44-45]}$. In another study, a DNA vaccine encoding full S protein of SARS-CoV U was shown to induce neutralizing antibodies and T-cell responses ${ }^{[46]}$. On the other hand, several vaccines targeting $\mathrm{S}$ protein have been developed against MERS-CoV, and it has been reported that RBD (receptor-binding domain) region of $S$ protein induces the highest level of IgG antibodies in mice ${ }^{[47]}$. Also, a DNA vaccine encoding subunit S1 of MERS-CoV spike protein was shown to induce humoral and cellular immune response in mice ${ }^{[48]}$. Cameron et al. (2007) reported that infected patients with fatal outcomes had a deficient 
antibody production against $S$ protein ${ }^{[49]}$. Clustering regions of B-lymphocyte and CTL epitopes in $\mathrm{N}$ and $\mathrm{M}$ proteins were also shown to induce antibody and T-cell responses in humans ${ }^{[50-54]}$.

\section{Potential cross-reactivity between SARS- CoV-2 and MERS-CoV}

Despite the similarity observed between antigenic peptides of SARS-CoV-2 and MERS$\mathrm{CoV}$, researchers do not agree regarding the presence of a potential cross-immunity between these two viruses. In fact, some authors have reported the absence of crossreactivity between SARS-CoV-2 and MERS$\mathrm{CoV}{ }^{[55-58]}$. Du et al. (2013) showed that monoclonal antibodies specific to SARSCoV RBD and serum polyclonal antibodies specific to SARS-CoV S-RBD didn't crossreact with or neutralize MERS-CoV [58]. However, another study on the structure of S2 region of spike protein of MERS-CoV and SARS-CoV, suggests that a T-cell cross reactivity might exist between MERS-CoV and SARS-CoV [38].

Sequence analysis of the four structural proteins (especially Spike protein) shows the conservation of antigenic peptides in SARSCoV and MERS-CoV S, N, M and E proteins, suggesting that cross-immunity could be possible between SARS-CoV-2 and MERS$\mathrm{CoV}$ since $\mathrm{S}$-protein is considered as the most antigenic component of coronaviruses [38, 44-45]. Table 3 summarizes some similarities between genomes and proteins of SARSCoV-2 and MERS-CoV.

\section{Hypothesis}

According to the statistical data reported during COVID-19 pandemic, there are less cases and deaths associated with COVID-19 in countries known for dromedary breeding practice (especially in Midle East and Africa). These countries are also known for the circulation of MERS-CoV (another betacoronavirus transmitted by dromedary camels) among humans and dromedaries. This findings and the similarity of genomes, antigenic peptides, and immunopathology of SARS-CoV-2 and MERS-CoV lead us to think that there is a potential cross-immunity between SARS-CoV-2 and MERS-CoV. Individuals from countries with dromedary breeding might have acquired immunity due to their contact with dromedaries, which protects them against SARS-CoV-2. A study performed in these countries reported that individuals with direct and indirect contact with dromedaries (Slaughterhouse worker, camel herders, etc.) and individuals consuming dromedary products (Milk, meat, and urine) had higher seropositivity rates for MERS-CoV compared to general population [17, 59-60].

The interest in investigating this potential cross-immunity between SARS-CoV-2 and MERS-CoV is due to the possibility of developing an anti-SARS-CoV-2 serotherapy using dromedary serum ${ }^{(61)}$. In fact, most studies targeting cross-immunity and serotherapy have been done on human or mouse sera, not on dromedary serum [28, 55${ }^{58]}$. Many neutralizing monoclonal antibodies (mAbs) targeting SARS-CoV spike protein have been reported to be produced in mouse ${ }^{[45]}$ or human sera ${ }^{[62-63]}$. Therapeutic approach based on anti-MERS-CoV neutralizing mAbs has been developed but not approved for commercial use [64-65].

Another interesting point about our hypothesis is the possible presence of other innate immune effectors such as complement proteins, chemokines, and especially AMPs (antimicrobial peptides) in dromedary serum, which are known for their effect not only on bacteria and fungi but also on enveloped viruses like coronaviruses [66].

\section{Conclusion}

In addition to vaccination, serotherapy could also play an important role against 
viral infections. Since a potential crossimmunity could exist between SARS-CoV-2 and MERS-CoV, there is a hope to develop a serotherapy using dromedary serum to fight COVID-19. Also, the same serum may contain other innate immune effectors such as complement proteins, chemokines, and antimicrobial peptides, which are effective against enveloped viruses like SARS-CoV-2. Acknowledgment: The authors are grateful to the computational service staff at the FST, SMS University.

Ethical Permission: Our study didn't need any "Ethical permission".

Conflict of interest: The authors state that there is no conflict of interest.

Authors' contribution: Conceptualization: AJ, HL; Investigation: SL; Methodology and project administration:

AJ, HL, SL; Supervision: AJ; Validation: HL; Writing of original draft: $A J, A B$; Writing, reviewing, and editing: $\mathrm{AJ}, \mathrm{ME}, \mathrm{AB}, \mathrm{HZ}$.

Fundings: This work did not receive any specific grant from funding agencies in the public, commercial, or not-for-profit sectors. Consent to participate: Not applicable.

\section{References}

1. Durand J, Jacquet M, Paillard L, Rais O, Gern L, Voordouw MJ. Cross-immunity and community structure of a multiplestrain pathogen in the tick vector. Appl Environ Microbiol. 2015;81(22):7740 -52 .

2. Bhattacharyyaa S, Gestelandc $\mathrm{PH}$, Korgenskic K, Bjørnstada ON, Adlerb FR. Cross-immunity between strains explains the dynamical pattern of paramyxoviruses. PNAS. 2015;112(43):13396-400.

3. Salazer G, Zhang N, Fu TM, An Z. Antibody therapies for the prevention and treatment of viral infection. Vaccines. 2017;2(1):1-2.

4. Beigel JH, Tebas $\mathrm{P}$, Elie-Turenne MC,
Bajwa E, Bell TE, Cairns CB, et al. Immune plasma for the treatment of severe influenza: An open-label, multicentre, phase 2 randomised study. Lancet Respir Med. 2017;5(6):500-11.

5. Gupta P, Kamath AV, Park S, Chiu H, Lutman J, Maia $M$, et al. Preclinical pharmacokinetics of MHAA4549A, a human mono-clonal antibody to influenza A virus, and the prediction of its efficacious clinical dose for the treatment of patients hospitalized with influenza A. MAbs, 2016;8(5):991-7.

6. Beltramello $\mathrm{M}$, Williams KL, Simmons CP, Macgno A, Simonelli L, Quyen NT, et al. The human immune response to Dengue virus is dominated by highly cross-reactive antibodies endowed with neutralizing and enhancing activity. Cell Host Microbe. 2010;8(3):271-83.

7. Robbie GJ, Crist R, Dall'acqua WF, Jensen K, Patel NK, Losonsky GA, et al. A novel investigational Fc-modified humanized monoclonal antibody, motavizumabYTE, has an extended half-life in healthy adults. Antimicrob Agents Chemother. 2013;57(12):6147-53.

8. Carbonell-Estrany $X$, Simões EA, Dagan $R$, Hall CB, Harris B, Hultquist $M$, et al. Motavizumab for prophylaxis of respiratory syncytial virus in highrisk children: A noninferiority trial. Pediatrics. 2010;125(1):e35-51.

9. Caskey M, Klein F, Lorenzi JC, Seaman MS, West AP Jr, Buckley $\mathrm{N}$, et al. Viraemia suppressed in HIV-1-infected humans by broadly neutralizing antibody 3BNC117. Nature. 2015;522(7557):487-91.

10. Welburn SC, Coleman PG, Zinsstag, J. Rabies control: Could innovative financing break the deadlock? Front Vet Sci. 2017;4:32.

11. Haagmans BL, Al Dhahiry SH, Reusken CB, Raj VS, Galiano M, Myers R, et al. 
Middle East respiratory syndrome coronavirus in dromedary camels: An outbreak investigation. Lancet Infect Dis. 2014;14(2):140-5.

12. Paden CR, Yusof $M, A l$ Hammadi ZM, Queen K, Tao Y, Eltahir YM, et al. Zoonotic origin and transmission of Middle East respiratory syndrome coronavirus in the UAE. Zoonoses Public Health. 2018;65(3):322-33.

13. Aguanno R, ElIdrissi A, Elkholy AA, Ben Embarek P, Gardner E, Grant R, et al. MERS: Progress on the global response, remaining challenges and the way forward. Antiviral Res. 2018;159:35-44.

14. Mehand MS, Al-Shorbaji F, Millett P, Murgue B. The WHO R\&D Blueprint: Review of emerging infectious diseases requiring urgent research and development efforts. Antiviral Res. 2018;159:63-7.

15. Zaki AM, van Boheemen S, Bestebroer TM, Osterhaus AD, Fouchier RA. Isolation of a novel coronavirus from a man with pneumonia in Saudi Arabia. N Engl J Med. 2012;367(19):1814-20.

16. World Health Organization (WHO). Middle East respiratory syndrome coronavirus (MERS-CoV). Geneva: World Health Organization; 2016.

17. Miguel E, Chevalier V, Ayelet G, Ben Bencheikh MN, Boussini $\mathrm{H}$, Chu DK, et al. Risk factors for MERS coronavirus infection in dromedary camels in Burkina Faso, Ethiopia, and Morocco, 2015. Euro Surveill. 2017;22(13):30498.

18. Sikkema RS, Farag EABA, Islam $M$, Atta M, Reusken CB, Al-Hajri MM, et al. Global status of Middle East respiratory syndrome coronavirus in dromedary camels: A systematic review. Epidemiol Infect. 2019;147:e84.

19. worldometer: https://www.worldometers. info/coronavirus

20. Ministère de la santé, Portail Officiel du
Coronavirus au Maroc, http://covidmaroc. ma/Pages/Accueil/AR.aspx

21. Minitère de la Santé, Portail Officiel de Coronavirus-Morocco

22. Fehr AR. and Perlman S. Coronaviruses: An overview of their replication and pathogenesis. Methods Mol Biol. 2015;1282:1-23.

23. Su S, Wong G, Shi W, Liu J, Lai ACK, Zhou J, et al. Epidemiology, genetic recombination, and pathogenesis of coronaviruses. Trends Microbiol. 2016;24(6):490-502.

24. Chen Y, Liu Q Guo D. Emerging coronaviruses: Genome structure, replication, and pathogenesis. J Med Virol. 2020;92(10):2249.

25. de Wit E, van Doremalen N, Falzarano D, Munster VJ. SARS and MERS: Recent insights into emerging coronaviruses. Nat Rev Microbiol. 2016;14(8):523-34. 26. Wu F, Zhao S, Yu B, Chen YM, Wang W, Song $\mathrm{ZG}$, et al. A new coronavirus associated with human respiratory disease in China. Nature. 2020;579(7798):265-9.

27. Huang C, Wang Y, Li X, Ren L, Zhao J, Hu Y, et al. Clinical features of patients infected with 2019 novel coronavirus in Wuhan, China. Lancet. 2020;395(10223):497506.

28. Chan JF, Yuan S, Kok KH, To KK, Chu $\mathrm{H}$, Yang J, et al. A familial cluster of pneumonia associated with the 2019 novel coronavirus indicating person-toperson transmission: A study of a family cluster. Lancet. 2020;395(10223):51423.

29. Nicholls JM, Poon LL, Lee KC, Ng WF, Lai ST, Leung CY, et al. Lung pathology of fatal severe acute respiratory syndrome. Lancet. 2003;361(9371):1773-8.

30. Wong CK, Lam CW, Wu AK, Ip WK, Lee $\mathrm{NL}$, Chan IH, et al. Plasma inflammatory cytokines and chemokines in severe acute respiratory syndrome. Clin Exp Immunol. 2004;136(1):95-103. 
31. Prompetchara E, Ketloy, Palaga T. Immune responses in COVID-19 and potential vaccines: Lessons learned from SARS and MERS epidemic. Asian Pac J Allergy Immunol. 2020;38(1):1-9.

32. Hussain S, Chen Y, Yang Y, Xu J, Pan $\mathrm{J}, \mathrm{Wu} \mathrm{Y}$, et al. Identification of novel subgenomic RNAs and noncanonical transcription initiation signals of severe acute respiratory syndrome coronavirus. J Virol. 2005;79(9):5288-95.

33. Risco C, Anton IM, Enjuanes L, Carrascosa JL. The transmissible gastroenteritis coronavirus contains a spherical core shell consisting of $\mathrm{M}$ and $\mathrm{N}$ proteins. J Virol. 1996;70(7):4773-7.

34. Eckerle LD, Becker MM, Halpin RA, Li K, Venter E, Lu X, et al. Infidelity of SARSCoV Nsp14-exonuclease mutant virus replication is revealed by complete genome sequencing. PLoS Pathog. 2010;6(5):e1000896.

35. Smith EC, Blanc $H$, Vignuzzi $M$, Denison MR. Coronaviruses lacking exoribonuclease activity are susceptible to lethal mutagenesis: Evidence for proofreading and potential therapeutics. PLoS Pathog. 2013;9(8):e1003565.

36. Mahallawi WH, Khabour OF, Zhang Q, Makhdoum HM, Suliman BA. MERS$\mathrm{CoV}$ infection in humans is associated with a pro-inflammatory Th1 and Th17 cytokine profile. Cytokine. 2018;104:813.

37. Zumla A, Hui DS, Perlman S. Middle East respiratory syndrome. Lancet. 2015;386(9997):995-1007.

38. Perlman S, Dandekar AA. Immunopathogenesis of coronavirus infections: Implications for SARS. Nat Rev Immunol. 2005;5(12):917-27.

39. Liu WJ, Zhao M, Liu K, Xu K, Wong G, Tan $\mathrm{W}$, et al. T-cell immunity of SARS-CoV: Implications for vaccine development against MERS-CoV. Antiviral Res.
2017;137:82-92.

40. Liu W, Fontanet A, Zhang PH, Zhan L, Xin ZT, Baril L, et al. Two-year prospective study of the humoral immune response of patients with severe acute respiratory syndrome. J Infect Dis. 2006;193(6):7925.

41. Al-Abdely HM, Midgley CM, Alkhamis AM, Abedi GR, Lu X, Binder AM, et al. Middle East respiratory syndrome coronavirus infection dynamics and antibody responses among clinically diverse patients, Saudi Arabia. Emerg Infect Dis. 2019;25(4):753-66.

42. Li CK, Wu H, Yan $\mathrm{H}$, Ma $\mathrm{S}$, Wang L, Zhang $\mathrm{M}$, et al. T cell responses to whole SARS coronavirus in humans. J Immunol. 2008;181(8):5490-500.

43. Lu G, Wang Q Gao G.F. Bat-to-human: Spike features determining 'host jump' of coronaviruses SARS-CoV, MERS$\mathrm{CoV}$, and beyond. Trends Microbiol. 2015;23(8):468-78.

44. Du L, He Y, Zhou Y, Liu S, Zheng BJ, Jiang S. The spike protein of SARS- CoVea target for vaccine and therapeutic development. Nat Rev Microbiol. 2009;7(3):226-36.

45. Keng CT, Zhang A, Shen S, Lip KM, Fielding BC, Tan TH, et al. Amino acids 1055 to 1192 in the S2 region of severe acute respiratory syndrome coronavirus $S$ protein induce neutralizing antibodies: Implications for the development of vaccines and antiviral agents. J Virol. 2005;79(6):3289-96.

46. Zhou T, Wang $H$, Luo D, Rowe T, Wang Z, Hogan RJ, et al. An exposed domain in the severe acute respiratory syndrome coronavirus spike protein induces neutralizing antibodies. J Virol. 2004;78(13):7217-26.

47. Yang ZY, Kong WP, Huang Y, Roberts A, Murphy BR, Subbarao K., et al. A DNA vaccine induces SARS coronavirus neutralization and protective immunity 
in mice. Nature. 2004;428(6982):561-4.

48. Tai W, Wang Y, Fett CA, Zhao G, Li F, Perlman $S$, et al. Recombinant receptorbinding domains of multiple Middle East respiratory syndrome coronaviruses (MERS-CoVs) induce cross-neutralizing antibodies against divergent human and camel MERS-CoVs and antibody escape mutants. J Virol. 2017;91(1):e01651-16.

49. Chi H, Zheng X, Wang X, Wang C, Wang $\mathrm{H}, \mathrm{Gai} \mathrm{W}$, et al. DNA vaccine encoding Middle East respiratory syndrome coronavirus S1 protein induces protective immune responses in mice. Vaccine. 2017;35(16):2069-75.

50. Cameron MJ, Ran L, Xu L, Danesh A, Bermejo-Martin JF, Cameron $\mathrm{CM}$, et al. Interferon-mediated immunopathological events are associated with atypical innate and adaptive immune responses in patients with severe acute respiratory syndrome. J Virol. 2007;81(16):8692-706.

51. Leung DT, Tam FC, Ma CH, Chan PK, Cheung JL, Niu H, et al. Antibody response of patients with severe acute respiratory syndrome (SARS) targets the viral nucleocapsid. J Infect Dis. 2004;190(2):379-86.

52. Lin Y, Shen X, Yang RF, Li YX, Ji YY, He YY, et al. Identification of an epitope of SARScoronavirus nucleocapsid protein. Cell Res. 2003;13(3):141-5.

53. Woo PC, Lau SK, Wong BH, Tsoi HW, Fung $\mathrm{AM}$, Chan KH, et al. Detection of specific antibodies to severe acute respiratory syndrome (SARS) coronavirus nucleocapsid protein for serodiagnosis of SARS coronavirus pneumonia. J Clin Microbiol. 2004;42(5):2306-9.

54. He Y, Zhou Y, Siddiqui P, Niu J, Jiang S. Identification of immunodominant epitopes on the membrane protein of the severe acute respiratory syndromeassociated coronavirus. J Clin Microbiol.
2005;43(8):3718-26.

55. Liu J, Wu P, Gao F, Qi J, Kawana-Tachikawa A, Xie J, et al. Novel immunodominant peptide presentation strategy: A featured HLA-A*2402-restricted cytotoxic T-lymphocyte epitope stabilized by intrachain hydrogen bonds from severe acute respiratory syndrome coronavirus nucleocapsid protein. J Virol. 2010;84(22):11849-57.

56. Agnihothram S, Gopal R, Yount Jr BL, Donaldson EF, Menachery VD, Graham RL, et al. Evaluation of serologic and antigenic relationships between Middle Eastern respiratory syndrome coronavirus and other coronaviruses to develop vaccine platforms for the rapid response to emerging coronaviruses. J Infect Dis. 2014;209(7):995-1006.

57. Meyer B, Drosten C, Muller MA. Serological assays for emerging coronaviruses: Challenges and pitfalls. Virus Res. 2014;194:175-83

58. Reusken C, Mou H, Godeke GJ, van der Hoek L, Meyer B, Muller MA, et al. Specific serology for emerging human coronaviruses by protein microarray. Euro Surveil. 2013;18(14):20441.

59. Du L, Ma C, Jiang S. Antibodies induced by receptor-binding domain in spike protein of SARS-CoV do not cross-neutralize the novel human coronavirus hCoV-EMC. J Infect. 2013;67(4):348-50.

60. Müller MA, Meyer B, Corman VM, AlMasri M, Turkestani A, Ritz D, et al. Presence of Middle East respiratory syndrome coronavirus antibodies in Saudi Arabia: A nationwide, crosssectional, serological study. Lancet Infect Dis. 2015;15(5):559-64.

61. Abbad A, Perera RAPM, Anga L, Faouzi A, Minh NNT, Malik SMMR, et al. Middle East respiratory syndrome coronavirus (MERS-CoV) neutralising antibodies in a high-risk human population, Morocco, 
November 2017 to January 2018. Euro Surveill. 2019;24(48):1900244.

62. Chouchane L, Grivel JC, Farag EA, Pavlovski I, Maacha S, Sathappan A, et al. Dromedary camels as a natural source of neutralizing nanobodies against SARSCoV-2. JCI Insight. 2021;6(5):e145785.

63. Traggiai E, Becker S, Subbarao K, Kolesnikova L, Uematsu Y, Gismondo MR, et al. An efficient method to make human monoclonal antibodies from memory B cells: Potent neutralization of SARS coronavirus. Nat Med. 2004;10(8):871-5.

64. Nie Y, Wang G, Shi X, Zhang H, Qiu Y, He Z, et al. Neutralizing antibodies in patients with severe acute respiratory syndromeassociated coronavirus infection. J Infect
Dis. 2004;190(6);1119-26.

65. Corti D, Zhao J, Pedotti M, Simonelli L, Agnihothram S, Fett C. et al. Prophylactic and post exposure efficacy of a potent human monoclonal antibody against MERS coronavirus. Proc Natl Acad Sci. 2015;112(33):10473-8.

66. Wang L, Shi W, Joyce MG, Modjarrad K, Zhang Y, Leung $\mathrm{K}$, et al. Evaluation of candidate vaccine approaches for MERSCoV. Nat Commun. 2015;6(1):7712.

67. Hsieh IN, Hartshorn KL. The role of antimicrobial peptides in influenza virus infection and their potential as antiviral and immunomodulatory therapy. Pharmaceuticals. 2016;9(3):53. 